\title{
CRITICAL-CARE DECISIONS ON NEONATES AND YOUNG CHILDREN IN ENGLAND AND WALES - LESSONS FOR SOUTH AFRICA*
}

\author{
Carina van der Westhuizen \\ BA HED MA(Latin) LLB LLD \\ Senior lecturer, Department of Private Law \\ University of South Africa (UNISA)
}

\begin{abstract}
SUMMARY
In this article it will be pointed out that in South Africa there are currently insufficient measures in place to protect the child patient, especially the neonate. A perusal of the case law of England and Wales reveals that in a number of cases on critical-care decisions the courts have used their opportunities to lay down criteria on issues such as the withholding or withdrawal of treatment in neonatal intensive care. These cases and the principles laid down in them may serve as precedents for South African case law. The English and Welsh courts have also provided guidelines on the interpretation of the best-interests standard in critical-care decisions. Guidelines on critical-care decisions were drafted by the Royal College of Paediatrics and Child Health, as well as the Nuffield Council on Bioethics. South Africa lacks such comprehensive guidelines on critical-care decisions concerning children. It is suggested that a comprehensive set of guidelines be drafted specifically for the unique South African position.
\end{abstract}

\section{INTRODUCTION}

To date very little research has been done in South Africa on the health care of neonates, and particularly on critically ill neonates and premature babies. In addition, there are presently insufficient measures in place to ensure proper health care for young children and neonates ${ }^{1}$ in South Africa. In this article it will be pointed out that current legislation ${ }^{2}$ falls short of providing adequate health care for premature babies, neonates, and young children in South Africa. This group of infants is not specifically protected in legislation, such as the Children's Act, ${ }^{3}$ nor is there a comprehensive set of guidelines available for use in critical-care decisions. The South African courts have not

* This article is partially based on the author's doctoral thesis A Proposed Framework for the Legal Protection of Premature and Critically ill Neonates in the Context of South African Child Law (University of the Free State 2012). The author is associated with the Biotechnology and Medical Law Flagship, College of Law, UNISA.

1 The Nuffield Council on Bioethics defines the neonatal period as the first 28 days after delivery. A neonate is therefore a baby of up to 28 days.

2 The Children's Act 38 of 2005; the National Health Act 61 of 2003; and the Consumer Protection Act 68 of 2008.

338 of 2005 . 
had the opportunity to give their view on the health care of young children, neonates and premature babies, since to date there has been only one reported case on this issue, namely Hay $v B{ }^{4}$

\section{BACKGROUND}

A perusal of the case law of England and Wales reveals a cautious approach to the withholding or withdrawal of medical treatment. The courts acknowledge that English law places a heavy burden on those who advocate treatment that will terminate human life. ${ }^{5}$ Before decisions on the withholding, withdrawal or even continuation of treatment are made, the court is often approached. It is requested to step in and make the final decision not only when there is disagreement between clinicians and parents, or between the parents, but also when there is no disagreement between the different parties, in which case the court as parens patriae ${ }^{6}$ of all minors is merely requested to sanction a decision by the parents and health-care professionals. ${ }^{7}$ Comprehensive guidelines were drafted by the Nuffield Council on Bioethics ${ }^{8}$ to provide additional protection to neonates and premature babies. To date no comprehensive set of guidelines on this subject has been drafted that would be accepted in all South African hospitals, both public and private. The only existing guidelines are those drafted by the Health Professions Council of South Africa. ${ }^{9}$ However, these are general in nature and applicable to all facets of health-care decisions in South Africa, and not specifically to neonates and premature babies.

The focus of this article will be the moment a foetus is born alive. No attention will be paid to the protection of the unborn foetus. Since the focus is not the foetus no attention will be given to maternal health, although this could influence prematurity or the health of a neonate. Forms of protection of premature babies, neonates and young children other than monetary compensation will be investigated. ${ }^{10}$

Neonates do not have a voice of their own and are therefore dependent upon others, such as their parents, health-care professionals, or in the last

42003 (3) SA 492 (W). This case will be dealt with in more detail later in this article. Cases in which monetary compensation was awarded for the neglect or misconduct of doctors are not considered in this article, whose focus is the protection of premature babies, neonates and young children through means other than monetary compensation to parents.

5 Re K (Medical Treatment: declaration) [2006] EWHC 1007 (Fam) [2006] 2 FLR 883 [48].

6 When the court as parens patriae is requested to make a decision on the treatment of a child, it steps into the shoes of the parents and takes over their parental rights and responsibilities. See Harper Medical Treatment and the Law. The Protection of Adults and Minors in the Family Division (1999) 26 and 49.

7 Fortin Children's Rights and the Developing Law 3ed (2009) 368. This was the case, eg, in In re C (a Minor) (Wardship: Medical treatment) [1989] 3 WLR 240 (CA).

8 Critical Care Decisions in Fetal and Neonatal Medicine: Ethical Issues. (2006). These will be discussed in more detail later in this article.

$9 \quad$ Guidelines for the Withholding and Withdrawing of Treatment 2ed (2007) Booklet 13.

10 Cases such as Edouard v Administrator, Natal 1989 (2) SA 368 (D\&CLD) and Friedman v Glicksman 1996 (1) SA 1134 (WLD), where monetary compensation was awarded for "wrongful birth" will not be considered here. 
instance, the court, to make decisions regarding their emotional, physical and emotional well-being. ${ }^{1}$

Although there have not been many legal disputes in England and Wales on the treatment of neonates or its withholding, in several cases that did reach the courts, decisions were made that furnished precedents for subsequent cases in England and Wales.

It will be pointed out that the position in England and Wales could serve as an example for South Africa. Should cases similar to the ones that reached the courts of England and Wales eventually reach South African courts, these cases should be used as precedents. Lastly, it will be suggested that guidelines similar to those drafted by the Nuffield Council on Bioethics ought to be drafted by a multidisciplinary team.

\section{THE COMMENCEMENT OF LEGAL SUBJECTIVITY}

In South Africa, as in England and Wales, once a baby is born alive he or she is regarded as a legal subject and enjoys all the rights of a legal subject, including the right to life as entrenched in the Bill of Rights ${ }^{12}$ of the Constitution and various human rights instruments. ${ }^{13}$ Since the unborn child is not regarded as a legal subject in South African law or the law of England and Wales, the foetus enjoys no legal protection in these jurisdictions. However, once a baby is born alive, no matter how deformed or premature, it enjoys all the rights of a legal person. ${ }^{14}$ According to Fortin this poses a dilemma for parents and health-care professionals alike; since on the one hand it means that every baby born alive has the right to life and should be kept alive by any means available. ${ }^{15}$ On the other hand, health-care professionals are not obliged to provide futile treatment, but the child's best interests should be the determining factor in making critical-care decisions. ${ }^{16}$ In English and Welsh case law it has been held that the decision not to provide futile medical treatment is not a contravention of Article $2^{17}$ of the European Convention on Human Rights, $1950^{18}$ or the Human Rights Act if such a decision is in the best interests of the patient. ${ }^{19}$ Article $3^{20}$ of the ECHR has also been invoked to assert the right to die with dignity. ${ }^{21}$

\footnotetext{
Bridgeman Parental Responsibility, Young Children and Healthcare Law (2007) 8.

S 11 of the Constitution of the Republic of South Africa, 1996.

Article 2 of the European Convention on Human Rights and Article 6(1) of the United Nations Convention on the Rights of the Child. See also Mason and Laurie Mason and McCall Smith's Law and Medical Ethics 8ed (2011) 479.

14 Alderson, Hawthorne and Killen "The Participation Rights of Premature Babies" 200513 The International Journal of Children's Rights 32; Boezaart Personereg 5ed (2010) 12; Heaton The South African Law of Persons 4ed (2012) 7; Fortin Children's Rights and the Developing Law 374; and Kruger and Skelton (eds) The Law of Persons in South Africa (2010) 22.

15 Fortin Children's Rights and the Developing Law 374-375.

16 Fortin Children's Rights and the Developing Law 375-376.

17 The right to life is protected in Article 2 of the ECHR.

18 Hereinafter "the ECHR".

19 Brazier and Cave Medicine, Patients and the Law 5ed (2011) 40. In Re A National Health Service Trust v D \& Ors [2000] 2 FLR 677, the court considered Articles 2 and 3 of the European Convention on Human Rights and held that it would not infringe D's right to life to
} 
What follows is a brief discussion of the legislation that affects neonates in England and Wales. Then court cases in which decisions were handed down that could serve as precedents for similar cases in South Africa will be considered. The guidelines drafted by the Nuffield Council for Bioethics will also be referred to briefly. Lastly I shall point out which lessons South Africa can learn from England and Wales, with specific reference to the guidelines of the Nuffield Council on Bioethics.

\section{LEGISLATION PERTAINING TO CHILDREN IN ENGLAND AND WALES}

In England and Wales legislation has been enacted to make provision for the health care of neonates and young children. ${ }^{22}$ The promulgation of the Children Act 1989 introduced a move away from parental rights to parental responsibilities. ${ }^{23}$ Since this change of emphasis, children have no longer been considered to be the property of their parents, although parents, not the state, have a responsibility to protect their children and their interests. ${ }^{24}$ The Children Act highlights the fact that the responsibility for their children rests primarily with parents and not the state. ${ }^{25}$ Section 1(1) of the Children Act $1989^{26}$ lies at the heart of all decisions to be made regarding the welfare of children. ${ }^{27}$ When the court is asked to intervene in the treatment of a newborn baby, it has to make a decision based on the best-interests standard (or the welfare principle, as it is also called). ${ }^{28}$

Article $8^{29}$ of the ECHR was given legal effect in the Children Act 1989, which means that it is state policy not to interfere in the private realm of family life as set out in section 1(5) of this Act. ${ }^{30}$ The state only fulfils the role

withdraw treatment and to allow him to die peacefully and with dignity if this would be in his best interests.

20 "No one shall be subjected to torture or to inhuman or degrading treatment or punishment."

21 Elliston "Treating the Preterm Infant - The Legal Context" in Norman and Greer (eds) Preterm Labour. Managing Risk in Clinical Practice (2005) 388.

22 Such as the Children and Young Persons Act 1933 and the Children Act 1989.

23 Bainham "Is Anything Now Left of Parental Rights?" in Probert, Gilmore and Herring (eds) Responsible Parents \& Parental Responsibility (2009) 23; and Fortin Children's Rights and the Developing Law 324.

24 Fletcher, Holt, Brazier and Harris Ethics, Law and Nursing (1995) 152.

25 Bridgeman Parental Responsibility, Young Children and Healthcare Law 228.

26 "[T]he child's welfare shall be the court's paramount consideration."

27 It is suggested that since the Children Act 1989 was drafted before the United Nations Convention on the Rights of the Child, 1989 was ratified by the United Kingdom in 1991, (see Fortin Children's Rights and the Developing Law 3) the term "welfare principle" be (?) used instead of the term "best interests of the child". The courts in England and Wales tend to use the two terms "welfare principle" and the "best interests" interchangeably. See Bridgeman Parental Responsibility, Young Children and Healthcare Law 101.

28 Fortin Children's Rights and the Developing Law 23; Harper Medical Treatment and the Law 49.

29 The right to respect for private and family life.

30 Bridgeman Parental Responsibility, Young Children and Healthcare Law 20; Featherstone "Gender, Rights, Responsibilities and Social Policy" in Wallbank, Choudhry and Herring (eds) Rights, Gender and Family Law (2010) 36. S 1(5) of the Children Act 1989 reads as follows: "Where a court is considering whether or not to make one or more orders under this 
of protector of children in need. ${ }^{31}$ The state will only intervene in the family realm and request care proceedings in terms of section $31 \mathrm{~A}$ of the Children Act if there is significant harm to the child in question. ${ }^{32}$

Although parents are the primary caretakers of their children, they are dependent on others with expert knowledge to enable them to fulfil their responsibilities. ${ }^{33}$ Parental responsibility is an important aspect of the health care of neonates, since consent for medical treatment of a very young patient must be obtained from someone who has parental responsibility for that child before a doctor may give treatment. ${ }^{34}$

In England and Wales persons with parental responsibility have a legal obligation to ensure that their children receive appropriate medical care. ${ }^{35}$ Parents who wilfully fail to seek adequate medical assistance or fail to take steps to provide such assistance when necessary, commit a criminal offence in terms of section 1(1) and (2) of the Children and Young Persons Act $1933^{36}$ of England and Wales. In terms of these sections parents can be found guilty of wilful neglect if they fail to provide a child with adequate treatment, which will result in suffering for the child and injury to his or her health. ${ }^{37}$ This Act was "designed to protect children from abuse by adults"38 and places an obligation on persons with parental responsibility to seek appropriate medical treatment when necessary. Failing to do so may constitute a criminal offence or lead to care proceedings. ${ }^{39}$ According to Kennedy and Grubb, ${ }^{40}$ a doctor cannot be held liable under this Act, since it is applicable only to persons with parental responsibility.

The Human Rights Act 1998 is influenced by the ECHR. ${ }^{41}$ This Act protects the individual's rights in two ways: Firstly, it is directly enforceable against public authorities and secondly, in terms of section 3 , all legislation

Act with respect to a child, it shall not make the order or any of the orders unless it considers that doing so would be better for the child than making no order at all."

Bridgeman Parental Responsibility, Young Children and Healthcare Law 228.

32 Freeman "The Best Interests of the Child? Is the Best Interests of the Child in the Best Interests of Children?" 1997 International Journal of Law, Policy and the Family 371.

33 Bridgeman "Children with Exceptional Needs: Welfare, Rights and Caring Responsibilities" in Wallbank, Choudhry and Herring (eds) Rights, Gender and Family Law (2010) 239.

34 Bridge "Religion, Culture and the Body of the Child" in Bainham, Sclater and Richards (eds) Body, Lore and Laws (2002) 265; and Harper Medical Treatment and the Law 8. No further discussion on parental responsibility will follow, since this is not the main focus of this article.

35 Hagger "Parental Responsibility and Children's Health Care Treatment" in Probert, Gilmore and Herring (eds) Responsible Parents \& Parental Responsibility (2009) 185.

36 Fortin Children's Rights and the Developing Law 646; and Herring Family Law 5ed (2011) 456.

37 Bridgeman Parental Responsibility, Young Children and Healthcare Law 85.

38 Herring Family Law 468.

39 Bridge in Bainham et al (eds) Body, Lore and Laws 276; Bridgeman Parental Responsibility, Young Children and Healthcare Law 85; Elliston in Norman and Greer (eds) Preterm Labour. Managing Risk in Clinical Practice 372; Hagger in Probert et al (eds) Responsible Parents \& Parental Responsibility 185-186. The effect of care proceedings is that the local authority takes care of a child. The local authority takes over the role of the parents. See Herring Family Law 581.

40 Medical Law 3ed (2000) 2165.

${ }^{41}$ Choudhry, Herring and Wallbank "Welfare, Rights, Care and Gender in Family Law" in Wallbank, Choudhry and Herring (eds) Rights, Gender and Family Law (2010) 3. 
must be interpreted in accordance with the Convention rights. ${ }^{42}$ It has been argued that the Convention does not protect children's rights adequately, since it contains no articles that specifically refer to them. ${ }^{3}$ The counterargument is that since children have the same rights as adults, they will receive the same protection as adults under this Convention.

Articles 2, 3 and 8 of the ECHR have been incorporated in Schedule 2 of the Human Rights Act. ${ }^{44}$ Bridgeman ${ }^{45}$ complains that the rights enunciated in the European Convention on Human Rights, which is adult-centred, and those in the United Nations Convention on the Rights of the Child ${ }^{46}$, which is primarily child-centred, have had little impact on the law relating to the health care of children in the United Kingdom. She goes on to say that, although in case law reference is made to the Human Rights Act 1998 and the CRC, both these human rights instruments have not influenced decisions much, since the courts are of the opinion that the "English common law is consistent with the Convention".

\section{SOUTH AFRICAN LEGISLATION}

Section 28(1)(c) of the Constitution of the Republic of South Africa, 1996 provides that every child has the right to basic health-care services. ${ }^{48}$ In terms of section 7(2) of the Constitution there is an obligation on the state to respect, protect, promote and fulfil the rights in the Bill of Rights. This right applies not only horizontally, but also vertically. The state not only has a duty to provide health-care services, but also has to ensure that third parties do not interfere with children's right to these services. ${ }^{49}$ The National Health $\mathrm{Act}^{50}$ gives effect to this constitutional right. In terms of section $4(3)(a)$ of the National Health Act, children below the age of six years who are not members or beneficiaries of medical-aid schemes, are entitled to free health services. Because this provision does not restrict the type of health-care services that should be provided at no cost, these should include not only primary or basic health-care services, but also expensive intensive care treatment. $^{51}$

Although the main text of the Children's Act $^{52}$ does not specifically refer to children's right to health care, it deals extensively with consent to medical

42 Choudhry et al in Wallbank et al (eds) Rights, Gender and Family Law 3; and Herring Medical Law and Ethics (2006) 227.

43 Herring Medical Law and Ethics 227.

44 Meyers "Wyatt and Winston-Jones: Who Decides to Treat or Let Die Seriously ill Babies?" 2005 9(2) Edinburgh LR 4-11.

45 Bridgeman Parental Responsibility, Young Children and Healthcare Law 19. See also Herring Family Law 36.

46 Hereinafter "the CRC".

47 Bridgeman Parental Responsibility, Young Children and Healthcare Law 19-20.

48 Büchner-Eveleigh and Nienaber "Gesondheidsorg vir Kinders: Voldoen Suid-Afrikaanse Wetgewing aan die Land se Verpligtinge Ingevolge die Konvensie oor die Regte van die Kind en die Grondwet?" 2012 15(1) PER 111.

49 lbid.

5061 of 2003.

51 See Büchner-Eveleigh and Nienaber 2012 15(1) PER 114-115.

5238 of 2005 . The preamble of the Children's Act refers to $s 28$ of the Constitution, which includes basic health-care services. 
treatment. ${ }^{53}$ Under normal circumstances a child's parent or guardian consents to medical treatment, but the Children's Act also makes provision for other interested parties to consent to life-saving treatment where the parents or guardians refuse or are unable to do so. In terms of section 129(10) of the Children's Act, a caregiver can also consent to medical treatment other than surgery.

Büchner-Eveleigh and Nienaber criticize the Children's Act, because it gives children only limited protection in respect of health-care services. The Act does not define the standard of health care of children. According to Büchner-Eveleigh and Nienaber, the Children's Act neither refers to the child's right to basic health-care services nor defines the minimum services that are required. ${ }^{54}$ In terms of section 27(2) of the Constitution, there is an obligation on the state to provide the rights referred to in section 27 within its available resources. ${ }^{55}$ Carstens and Pearman point out that there is no similar provision in section 28 of the Constitution. ${ }^{56}$ They point out that one could argue that the minimum core of health-care services is not applicable in the case of children. ${ }^{57}$ However, the Constitutional Court rejected the minimum core concept in both the Grootboom ${ }^{58}$ and TAC $^{59}$ cases. $^{60}$ In conclusion it can be said that the state is obliged only to provide health care to children when the parents are unable to provide the necessary health care to their children. ${ }^{61}$ Moreover, the right to health care of children is not a separate right, but a facet of socio-economic rights. ${ }^{62}$

In terms of the Consumer Protection $\mathrm{Act}^{63}$ there is an obligation on a service provider - in this case the health-care professional - to provide quality and timely service. Section 54 of the CPA should be read together with section 3, which sets out the purpose of the Act, namely to protect vulnerable groups. ${ }^{64}$ These two sections refer to medical services to children. The Act provides for the enforcement of consumers' rights by means of various remedies. ${ }^{65}$

A child who is physically, mentally or socially harmed or is at risk of being physically, mentally or socially harmed is a child in need of care and

53 See also Büchner-Eveleigh and Nienaber 2012 15(1) PER 113.

54 Büchner-Eveleigh and Nienaber 2012 15(1) PER 120.

55 This was confirmed in Soobramoney $v$ Minister of Health (KwaZulu-Natal) 1998 (1) SA 765 1997 (CC).

56 Carstens and Pearmain Foundational Principles of Medical Law (2007) 78.

57 lbid.

58 Government of the Republic of South Africa v Grootboom 2001 (1) SA 46 (CC).

59 Minister of Health $v$ Treatment Action Campaign (No 2) 2002 (5) SA 721 (CC).

60 Carstens and Pearmain Foundational Principles of Medical Law 78-79.

61 Schäfer Child Law in South Africa (2011) 131.

62 Carstens and Pearmain Foundational Principles of Medical Law 81.

6368 of 2008 (hereinafter "the CPA"). S 54(1)(a) and (b) reads as follows: "When a supplier undertakes to perform any services for or on behalf of a consumer, the consumer has a right to (a) the timely performance and completion of those services, and timely notice of any unavoidable delay in the performance of the services; (b) the performance of the services in a manner and quality that persons are generally entitled to expect."

64 See Jacobs, Stoop and Van Niekerk "Fundamental Consumer Rights under the Consumer Protection Act 68 of 2008: A Critical Overview" 2010 13(3) PER 304.

65 Jacobs et al 2010 13(3) PER 307. It falls outside the scope of this article to discuss these remedies in detail. 
protection. ${ }^{66}$ Section 151 of the Children's Act determines that if a child is found to be in need of care and protection in terms of section 150, that child may be removed from the care of a person with parental responsibilities and rights and be temporarily placed in safe care by a social worker after a court order to this effect has been obtained.

South Africa lacks legislation such as the Children and Young Persons Act 1933 of England and Wales that places a legal obligation on parents or caretakers to ensure that children receive appropriate medical treatment, and provides that failure to do so may lead to conviction for a criminal offence or care proceedings. Sections 150 and 151 of the Children's Act do not criminalize failure to seek appropriate medical treatment for a child.

It may thus be seen that ill neonates and children do not completely lack legal protection, but protection is to be found in various laws, not a single Act. This makes it difficult to determine exactly which health-care rights children, in general, and neonates in particular, have. ${ }^{67}$

\section{CONSENT TO MEDICAL TREATMENT}

In terms of the law of England and Wales it is unlawful for doctors to give medical treatment without obtaining the necessary consent from a competent patient himself or herself or, in the case of neonates, from someone with parental responsibility or someone authorized to give the necessary consent. ${ }^{68}$ In exceptional cases, namely where there is an emergency or a child has been abandoned or the parents cannot be found, ${ }^{69}$ health-care professionals may dispense with the consent requirement, act under the common-law doctrine of necessity and immediately provide lifesaving treatment. ${ }^{70}$ Apart from these exceptional cases, verbal or written consent is required, and in its absence medical treatment constitutes assault, no matter how beneficial the proposed treatment may be in the doctor's opinion. ${ }^{71}$ Section 3(5) of the Children Act 1989 provides that a person in whose care a child is left may "do what is reasonable in all the circumstances of the case for the purpose of safeguarding or promoting the child's welfare", even though such a person does not have parental responsibility.

The decision in David Glass ${ }^{72}$ is a landmark one on consent given by a surrogate decision-maker, such as a parent. In casu David Glass was a severely ill child. He had been physically and mentally disabled since birth.

\section{S 150(1)(f)-(i) of the Children's Act 38 of 2005.}

67 Büchner-Eveleigh and Nienaber 2012 15(1) PER 136.

68 Fortin Children's Rights and the Developing Law 367; and Harper Medical Treatment and the Law 8.

69 Harper Medical Treatment and the Law 8.

70 Harper Medical Treatment and the Law 81-82. In Re OT (a Baby) [2009] EWHC 635 (Fam) the parents argued that an emergency application was procedurally unfair and claimed that it was an infringement of Baby OT's rights in terms of Article 8 of the European Convention on Human Rights, namely his right to respect for private and family life. See also Brazier and Cave Medicine, Patients and the Law 435.

71 Brazier and Cave Medicine, Patients and the Law 116; Elmalik and Wheeler "Consent: Luck or Law?" 2007 Annual Royal College of Surgeons of England 627.

72 Glass v United Kingdom [2004] 1 FLR 1019 (ECtHR). 
Health-care professionals believed that he was dying and without first obtaining his mother's permission or a court order, nursing staff put up a notice that he was not to be resuscitated and that diamorphine should be administered to him. After approaching the English courts without success, David's mother turned to the European Court of Human Rights. The European Court of Human Rights held that, in neither obtaining the mother's permission nor a court order, the health-care professionals had infringed David's right to respect for private and family life, which was guaranteed in article 8 of the ECHR. ${ }^{73}$ Although the European Court of Human Rights ruled that parental consent was necessary before any form of medical treatment might be provided, and that a court order had to be sought when parents objected to a specific course of action, it did not hold that health-care professionals should always comply with the parents' wishes. ${ }^{74}$

\section{DISAGREEMENT BETWEEN HEALTH PRO- FESSIONALS AND CARERS AND PARENTS}

\section{Introduction}

In certain cases, parents, carers and health professionals may disagree on whether a particular treatment would be in the best interests of the child. When such a matter is brought to court it has to decide the case according to the best-interests-of-the-child or the welfare principle. It then has the difficult task of balancing the rights of the health-care professionals and the parents on the one hand, and the best interests of the child patient on the other. It is no easy task for the court to decide what is in the best interests of a particular child, this being a standard that has often been criticized for being indeterminate. ${ }^{75}$

There are two factors to consider with regard to the best interests of the child. Firstly, the poor quality of life of the baby or the child may continue if the requested treatment is provided and proves successful. Secondly, it may not be in the best interests of the child to provide treatment in the first place. $^{76}$

When there is a dispute between parents regarding the treatment of their baby or child, the court may be approached for a declaratory order in terms of the court's inherent jurisdiction or a specific issue order in terms of section 8 of the Children's Act $1989 .{ }^{77}$ In terms of a specific issue order the court takes over parental responsibilities and rights. A specific issue order by the

3 See also Brazier and Cave Medicine, Patients and the Law 435.

74 Elliston in Norman and Greer (eds) Preterm Labour. Managing Risk in Clinical Practice 382.

75 Fortin Children's Rights and the Developing Law 292-293; Hagger in Probert et al (eds) Responsible Parents \& Parental Responsibility 191; and Harper Medical Treatment and the Law 13.

76 Harper Medical Treatment and the Law 14.

77 Bridgeman Parental Responsibility, Young Children and Healthcare Law 99; Hagger in Probert et al (eds) Responsible Parents \& Parental Responsibility 186. In terms of s 8 of the Children Act 1989 "'a specific issue order' means an order giving directions for the purpose of determining a specific question which has arisen, or which may arise, in connection with any aspect of parental responsibility for a child". 
court may take two forms: firstly it may be a prohibiting order that prohibits parents from taking any steps contrary to the order without the court's consent. Secondly it may be imperative in the sense that the court determines a specific question on any aspect of parental responsibility. These two orders may also be granted in the same order. ${ }^{78}$ The court may also order care proceedings, ${ }^{79}$ but only after the local authority has requested such proceedings with the leave of the court. ${ }^{80}$ The courts indicate the appropriate course that should be followed, based on the best interests of the child. ${ }^{81}$

From a perusal of reported decisions, it becomes clear that there are three types of critical-care decisions: firstly the ones where the parents and health-care professionals disagree, secondly the ones where it has to be determined whether life-saving treatment should be withdrawn or withheld, and thirdly the ones where the courts are requested to authorize a particular course of action decided on by parents and health-care professionals. It should be noted that the courts do not order that a particular treatment be provided, but merely authorize it. ${ }^{82}$

A study of certain English and Welsh court cases will demonstrate to what extent the courts were influenced by the parents' views and the factors that the court considered in determining the best interests of the baby. ${ }^{83}$

In most cases, courts are hesitant to dictate to doctors how they should treat their patients, and defer to the doctors' professional discretion. ${ }^{84}$ Ultimately the court's decision is based on what would be in the best interests of a particular child patient. A balance sheet is drawn up that reflects the benefits and disadvantages of the proposed treatment, and then the most beneficial approach is followed. ${ }^{85}$

\section{Case studies}

A few court cases illustrating the approach of the English and Welsh courts will now be discussed.

78 Mitchell Children Act Private Law Proceedings: A Handbook 2ed (2006) 75-76.

79 In terms of $s$ 38(6) of the Children Act 1989: (6): "Where the court makes an interim care order, or interim supervision order, it may give such directions (if any) as it considers appropriate with regard to the medical or psychiatric examination or other assessment of the child; but if the child is of sufficient understanding to make an informed decision he may refuse to submit to the examination or other assessment."

80 S 100(3) of the Children Act 1989 reads as follows: "No application for any exercise of the court's inherent jurisdiction with respect to children may be made by a local authority unless the authority has obtained the leave of the court."

81 Hagger in Probert et al (eds) Responsible Parents \& Parental Responsibility 186.

82 Elliston in Norman and Greer (eds) Preterm Labour. Managing Risk in Clinical Practice 378.

83 Bridge in Bainham et al (eds) Body, Lore and Laws 270.

84 Harper Medical Treatment and the Law 19-20.

85 Bridgeman Parental Responsibility, Young Children and Healthcare Law 99; Bridgeman in Wallbank et al (eds) Rights, Gender and Family Law 240-241; Elliston in Norman and Greer (eds) Preterm Labour. Managing Risk in Clinical Practice 375; Hagger in Probert et al (eds) Responsible Parents \& Parental Responsibility 186; and Mason and Laurie Mason and McCall Smith's Law and Medical Ethics 480-481. 
As mentioned above, doctors and health-care professionals cannot pursue a specific course of action that is contrary to the wishes of the parents, unless they obtain a court order ${ }^{86}$ The locus classicus in English and Welsh law in this regard is the case of baby Alexandra (also known as baby B). ${ }^{87}$ Baby Alexandra was born suffering from Down's Syndrome as well as an intestinal blockage. The doctors wanted to operate to save her life by removing the blockage. However, her parents refused to give the necessary consent to the surgery, since they believed that "it would be unkind to this child to operate upon her". ${ }^{88}$ They believed that "God or nature has given the child a way out." ${ }^{\circ 9}$ In their view it was in baby Alexandra's best interests that she not undergo surgery, because although her life would be saved, she would still be severely physically and mentally handicapped. In this case medical opinion was also divided: one surgeon was in favour of parental autonomy and felt that the parents' views had to be respected, while another believed that the parents' objections should be overruled and that it was in the best interests of baby $B$ to undergo surgery.

The question the court had to consider was whether it was in the best interests of the child to allow her to die or else to authorize an operation that would remove the blockage, in which case she would have the normal life span of a person suffering from Down's Syndrome, albeit with physical and mental handicaps. If not operated on, Baby Alexandra would in all likelihood die within days. The court had to weigh up the risks and benefits of the proposed surgery against the quality of life the baby would experience after surgery. ${ }^{90}$ What was in the best interests of the child was no longer the parents' decision, but that of the court. ${ }^{91}$ The court a quo refused to authorize the operation. However, the Court of Appeal overruled the parents' wishes and ordered that it be performed. ${ }^{92}$ Lord Justice Templeman formulated the crucial test that was followed in subsequent cases, namely that the court had to decide "whether the life of this child is demonstrably going to be so awful that in effect the child must be condemned to die, or whether the life of this child was still so imponderable that it would be wrong for her to be condemned to die.",93 The court held that after successful surgery Baby Alexandra would still be able to live the normal life span of a person with Down's syndrome and that her life would not be "demonstrably awful". This case also established the principle that parents' autonomy is restricted so that once a child is born they do not have the power of life and death over it. ${ }^{94}$

The In re $B$ decision was criticized by scholars in the United Kingdom. On the one hand there were those who believed that ultimately the decision whether a severely handicapped child should be treated should be made by

\footnotetext{
Elliston in Norman and Greer (eds) Preterm Labour. Managing Risk in Clinical Practice 367. In re B (a Minor) (Wardship: Medical Treatment) [1981] 1 WLR 1421 (CA).

In re B (a Minor) (Wardship: Medical Treatment) supra 1422

In re B (a Minor) (Wardship: Medical Treatment) supra 1424.

Bridge in Bainham et al (eds) Body, Lore and Laws 271.

In re B (a Minor) (Wardship: Medical Treatment) supra 1424.

See also Brazier and Cave Medicine, Patients and the Law 423.

93 In re $B$ (a Minor) (Wardship: Medical Treatment) supra 1424. See also Brazier and Cave Medicine, Patients and the Law 430.

94 Fortin Children's Rights and the Developing Law 382.
} 
its parents, not by a court. ${ }^{95}$ On the other hand there were those who argued that parents could not decide whether a child should live or die, and that court intervention was the correct route to follow, since the court was the parens patriae of a child whether or not he or she was a ward of court. ${ }^{96}$

The dilemma courts are faced with in applying the best-interests-of-a-child principle is also illustrated by the decision in $\ln$ re $T .^{97}$ In this case $\mathrm{T}$ (also referred to as baby $\mathrm{C}$ ) suffered from biliary atresia and medical opinion was unanimous that he would not survive beyond the age of two-and-a-half years without a liver transplant, yet his parents refused to consent to the operation. The hospital approached the local authority, which in turn asked the court, in terms of section 100(3) of the Children Act 1989, to exercise its inherent wardship jurisdiction and order the liver transplant to go ahead. ${ }^{98}$ The court $a$ quo overruled the parents' refusal, while the Court of Appeal decided in favour of the parents. It emphasized that each case should be decided on its own facts. ${ }^{99}$ Usually the courts do not make an order that conflicts with the clinical judgment or medical opinion of health-care professionals. This is one of a few reported cases in which the decision went against medical opinion and in favour of the parents. ${ }^{100}$ There were other factors which also influenced the court's decision. The parents fled the United Kingdom, having decided to live and work abroad in order to escape interference by the social services. The child had undergone unsuccessful surgery when he was only three-and-a-half weeks old, which caused him pain and distress. Both parents were health professionals and experienced in treating ill children. ${ }^{101}$ In casu the court refused to authorize the liver transplant and by doing so emphasized parental authority. ${ }^{102}$ The parents felt that their child's best interests would be best served by focusing "on the present peaceful life of the child who had the chance to spend the rest of his short life without the pain, stress and upset of intrusive surgery against the future with the operation and treatment taking place."

Opinion has been divided on this decision: Some scholars argue that it was correct and that parents' interests should be taken into account, while others consider that it gave parents autonomy to decide whether their children should be allowed to live or die. ${ }^{104}$ Freeman ${ }^{105}$ argues that this case was not correctly decided from the point of view of the child's best interests. He says: "There is surely a distinction, which Best Interests does not

95 Freeman "Freedom and the Welfare State: Child-rearing, Parental Autonomy and State Intervention" 1983 Journal of Social Welfare Law 88.

96 Ibid; and Harper Medical Treatment and the Law 26.

97 In re T (a Minor) (Wardship: Medical Treatment) [1997] 1 WLR 242 (CA).

98 Harper Medical Treatment and the Law 84.

99 See also Brazier and Cave Medicine, Patients and the Law 431-432; Harper Medical Treatment and the Law 84; and Mason and Laurie Mason and McCall Smith's Law and Medical Ethics 495.

100 Elliston in Norman and Greer (eds) Preterm Labour. Managing Risk in Clinical Practice 380 and 381 .

101 Brazier and Cave Medicine, Patients and the Law 433; Harper Medical Treatment and the Law 84; and Herring Family Law 453.

102 Harper Medical Treatment and the Law 84.

103 In re T (a Minor) (Wardship: Medical Treatment) supra 251

104 Hagger in Probert et al (eds) Responsible Parents \& Parental Responsibility 189-190.

105 Freeman 1997 International Journal of Law, Policy and the Family 376-377. 
acknowledge, between giving parents some autonomy, and allowing someone else to review the decision they take." ${ }^{, 106}$ Herring also criticized the decision. According to him the court failed to consider alternative care and the "court placed excessive weight on the parents' views and insufficient weight on the child's right to life."107 Fortin, too, criticizes the decision and said: "[H]opefully it has now been relegated to the history books." However, scholars such as Bridgeman welcomed the decision: "The judgment of the Court of Appeal is to be welcomed for the attempt to acknowledge the role of C's mother and to recognize her expertise and interest in his well-being." 109

The In re $C^{110}$ case reflects the cautious approach followed in England and Wales. Although there was no disagreement between the parents and health-care professionals, baby $\mathrm{C}$ was made a ward of court shortly after her birth because the social services feared that her parents would not be able to care for her. ${ }^{111}$ Since baby $\mathrm{C}$ was a ward of court, any major decisions regarding her care had to be made by the court. Baby $\mathrm{C}$ was born prematurely with congenital hydrocephalus and also malformation of the brain. By the time this application was heard she was dying and her prognosis would be hopeless even if she were to be given the best available treatment. Her parents and health-care professionals agreed that it would be in her best interests to withdraw mechanical ventilation, since this only prolonged her suffering, and to sedate her and provide only palliative care. The question the court had to decide was what treatment would be in C's best interests. It held that it would be in her best interests to be given only palliative care and that she should be allowed to die peacefully and with dignity. ${ }^{112}$

Although the courts will not usually pronounce a judgment that conflicts with the clinical view of medical experts, they are not insensitive to parents' views, as is illustrated by a case, confusingly also called In re $C,{ }^{13}$ but in which judgment was handed down about seven years after the first one. Baby $\mathrm{C}$ was born prematurely and contracted meningitis, which resulted in brain damage, deafness and blindness. As her parents and health-care professionals agreed that it would be in her best interests to discontinue mechanical ventilation, they approached the court to make an order to that effect. The court ordered that life support be withdrawn. There was no dispute between baby C's parents and the health-care professionals; they merely wanted the court to sanction their decision so that no party would be at risk of subsequent prosecution. ${ }^{114}$ The relevance of this case is that it

106 Freeman 1997 International Journal of Law, Policy and the Family 377.

107 Herring Family Law 422.

108 Fortin Children's Rights and the Developing Law 384

109 Bridgeman Parental Responsibility, Young Children and Healthcare Law 141-142.

110 In re C (a Minor) (Wardship: Medical Treatment) supra.

111 In re C (a Minor) (Wardship: Medical Treatment) supra 242.

112 In re C (a Minor) (Wardship: Medical Treatment) supra 241. See also Brazier and Cave Medicine, Patients and the Law 429; Bridgeman Parental Responsibility, Young Children and Healthcare Law 160-161; Fletcher, Holt, Brazier and Harris Ethics, Law and Nursing 149; and Mason and Laurie Mason and McCall Smith's Law and Medical Ethics 482.

113 In re C (a Baby) [1996] FLR 43.

114 See also Brazier and Cave Medicine, Patients and the Law 429. 
demonstrates that after the case of baby Alexandra the law had developed to the point where the court was now prepared to acknowledge that a child's life need not be preserved at all cost.

In $R e J^{115}$ the court drew up a balance sheet of the benefits and burdens of treatment and held that the burdens of the proposed treatment outweighed its benefits. In this case "intolerability" was formulated as the criterion in deciding whether to withdraw or withhold treatment. The dilemma the court faced was that Baby $\mathrm{J}$ was not dying. The court drew up the balance sheet in order to assess the baby's quality of life..$^{116}$

The court was also not willing to order life support to be withdrawn from a baby suffering from the congenital disease Spinal Muscular Atrophy. ${ }^{117}$ Following the decision in $R e J$ the court also drew up a balance sheet of the benefits and burdens of treatment. However, in this unusual case, although the burdens of continued treatment by far outweighed its benefits, the court nevertheless did not authorize the withdrawal of mechanical ventilation but emphasized the fact that the parents did not want ventilation to be withdrawn even though, according to medical opinion, the baby's condition was deteriorating.

In a more recent case ${ }^{119}$ the NHS Trust sought a declaratory order that it would be lawful not to resuscitate a dying baby if he stopped breathing. The court held that if it was in the best interests of the child to withdraw mechanical ventilation, it would not be a violation of Article 2 of the European Convention on Human Rights to do so since the ventilation was a painful and intrusive process that did not offer lasting benefit and that the child should be allowed to die peacefully and with dignity. ${ }^{120}$ This right is protected under article 3 of the ECHR, which protects the right not to be subjected to inhuman or degrading treatment. ${ }^{121}$ This is an example of a decision in which the court relied on medical evidence and overruled the parents' wishes. The court held that an order to withhold treatment would neither infringe the child's right to life entrenched in article 2 of the European Convention on Human Rights, nor the child's right not to be subjected to inhuman or degrading treatment entrenched in article 3.

This was confirmed in two subsequent cases. In $A$ National Health Service Trust $v D$ \& Ors ${ }^{122}$ Baby I was suffering from a severe, chronic and irreversible lung disease, as well as heart failure and hepatic and renal dysfunction. ${ }^{123}$ The National Health Service Trust was seeking an order that

115 In re J (a Minor) (Wardship: Medical treatment) [1991] 2 WLR (CA) 140 - case heard in 1990 and reported in 1991.

116 See Mason and Laurie Mason and McCall Smith's Law and Medical Ethics 482.

117 Hereinafter "SMA".

118 An NHS Trust v MB [2006] EWHC 507 (Fam). See also Brazier and Cave Medicine, Patients and the Law 417, 438-439.

119 A National Health Service Trust $v D$ \& Ors supra. The child in question suffered from chronic and irreversible lung disease as well as heart, renal and liver problems. The health authority applied for an order that mechanical ventilation be withheld should the child suffer cardiac or respiratory failure.

120 Brazier and Cave Medicine, Patients and the Law 430.

121 Bridgeman in Wallbank et al (eds) Rights, Gender and Family Law 248.

122 Supra.

${ }^{123}$ A National Health Service Trust v D \& Ors supra [3]. 
the baby not be resuscitated should he suffer respiratory and/or cardiac failure or arrest. The court reiterated the general legal principles that apply in such cases, the first and primary consideration being the child's best interests. ${ }^{124}$ The sanctity-of-life principle imposes a strong obligation on health-care professionals to take steps to prolong life, ${ }^{125}$ and finally the court will not easily compel a doctor to provide treatment that goes against his clinical judgment. ${ }^{126}$ The court held that the order sought, namely that mechanical ventilation not be provided, would not be a contravention of articles 2 or 3 of the ECHR.

In a more recent case ${ }^{128}$ a baby (OT) suffered severe, irreversible brain damage. The hospital sought an order that mechanical ventilation be discontinued and that only palliative treatment be given, since the treatment was considered to be futile and would cause further distress to OT. The parents disagreed with the clinical judgment of the doctors and opposed the application. The court held that the withdrawal of life-sustaining treatment would not be a breach of articles 2,3 or 8 of the $\mathrm{ECHR}^{129}$ since the treatment was no longer in the best interest of OT. ${ }^{130}$ Here the court considered the position from the point of view of the patient. ${ }^{131}$

In a similar case, the hospital brought an application for an order that a feeding tube be removed from the abdomen of baby $\mathrm{K}$, that palliative care then be provided and that she be allowed to die peacefully. ${ }^{132}$ In this case the court reiterated that children cannot make their own decisions about their health care, but need surrogate decision-makers. Since baby $\mathrm{K}$ could not even experience "the simple pleasure of being alive or having other than a life dominated by regular pain, distress and discomfort" ${ }^{133}$ the court applied the best-interests standard and held that it would be in her best interests if tubular nutrition were discontinued and she be allowed to die peacefully.

Recently English and Welsh courts shed more light on the criteria that should be applied in similar cases by listing those that determine the best interests of a child patient. ${ }^{134}$ The court should bear in mind that the best interests (or the welfare of the child) are of paramount importance. This should be considered from the point of view of the patient. Since the courts have great respect for the principle of "sanctity of life", there is a strong but not irrebuttable presumption in favour of courses of action that will prolong

\footnotetext{
A National Health Service Trust $v$ D \& Ors supra [48].

A National Health Service Trust $v$ D \& Ors supra [49].

A National Health Service Trust $v$ D \& Ors supra [51].

A National Health Service Trust $v$ D \& Ors supra [82].

In Re OT (a Baby) supra.

The right to life, the prohibition of torture and respect for private and family life.

In Re OT (a Baby) supra [98].

In Re OT (a Baby) supra [164]

${ }^{32}$ Re K (Medical Treatment: declaration) supra.

${ }^{33}$ Re K (Medical Treatment: declaration) supra [57].

134 NHS Trust $v$ Baby $X$ \& Ors [2012] EWHC 2188 (Fam). In this case baby $X$ suffered an accident that resulted in severe brain damage. The hospital staff was of the opinion that it would not be in his best interests to keep him on mechanical ventilation since his condition would not improve. His parents, however, wanted mechanical ventilation to continue. The court made a declaration, not an order of court, that baby $\mathrm{X}$ should receive palliative care only and that this would be lawful as being in the baby's best interests.
} 
life. In casu the court held that the best interests encompassed medical, emotional and all other welfare issues, as well as psychological and social benefits. ${ }^{135}$ The court confirmed the decision in $R e J{ }^{136}$ In the latter case the court did a balancing exercise by drawing up a list of the benefits and burdens of the proposed treatment in order to relieve the tension between saving life on the one hand and avoiding distress and suffering on the other. The court needs to conduct a balancing exercise by weighing the benefits and burdens of the proposed treatment in order to reach a decision that will have the best overall benefit. ${ }^{13}$

In another case ${ }^{138}$ there was disagreement between the parents at the beginning of the court hearing. Both parents eventually agreed with the health-care professionals that it would be in the best interests of the baby to allow him to die peacefully and with dignity.

\section{South African case law}

The only reported case in South African law in which there was conflict between parents and health-care professionals, is Hay $v B .^{139} \mathrm{~A}$ paediatrician brought an urgent application to the High Court for a blood transfusion to be administered to a child who would not be able to survive without it. The parents objected to the transfusion, since it was against the tenets of their religion and they were concerned about the risk of infection. The court held that the blood transfusion could be administered since the parents' religious beliefs could be trumped by the child's right to life. ${ }^{140}$

There could be various reasons why, apart from Hay $v B$, similar cases have not reached South African courts. In my view, possible reasons include the following:

- Parents do not challenge health-care professionals' decisions on the treatment of their offspring.

- Health-care professionals and parents reach agreement privately.

- The cost of litigation discourages people from approaching the court.

- Cases may be settled out of court.

- This is an emotional issue and people may feel that a court is not the correct forum in which to settle it.

135 In re J (a Minor) (Wardship: Medical treatment) supra 149. See also Hagger in Probert et al (eds) Responsible Parents \& Parental Responsibility 186; and Harper Medical Treatment and the Law 31, 38, 51 and 83. This was reiterated in Re OT (a Baby) supra [98]

136 In re J (a Minor) (Wardship: Medical Treatment) supra 149.

137 Elliston in Norman and Greer (eds) Preterm Labour. Managing Risk in Clinical Practice 364; and Hagger in Probert et al (eds) Responsible Parents \& Parental Responsibility 186. In Re $J$ (a Minor) (Wardship: Medical Treatment) supra 149, Lord Donaldson held that "that there is a balancing exercise to be performed in assessing the course to be adopted in the best interests of the child".

138 Re RB (a Child) [2009] EWHC 3269 (Fam).

139 Supra.

140 Kassan and Mahery "Special Child Protective Measure in the Children's Act" in Boezaart (ed) Child Law in South Africa (2009) 217-218. 
- Unlike the NHS Trust in England and Wales, public hospitals in South Africa do not have the financial resources to engage in litigation if there is disagreement between parents and health-care professionals. The NHS Trust has taken several such matters to court in England and Wales.

It is suggested that as parents become better informed, cases in which there is disagreement between health-care professionals and parents will be the subject of judicial scrutiny in South Africa. In my view, the English and Welsh cases that have been reported could serve as precedents in similar South African cases.

\section{PROFESSIONAL GUIDELINES}

Before the the Nuffield Council on Bioethics drafted guidelines, the Royal College of Paediatrics and Child Health ${ }^{141}$ issued a document entitled "A Framework for Practice in relation to Withholding or Withdrawing Life-saving Treatment in Children" in September 1997. This important document provides a framework for medical practitioners that will help them decide when to withhold or withdraw treatment from a child. ${ }^{142}$ In this document five situations where this question may arise are identified, namely one where the child is brain dead, one where the child is in a permanent vegetative state, the "no chance situation", the "no purpose" situation ${ }^{143}$ and the "unbearable" situation. ${ }^{144}$ The first four amount to medical futility, while the last is the most controversial. This is illustrated in the case confusingly also called In re $J{ }^{145}$ where the baby was not dying, but had sustained severe head injuries which caused microcephaly. Medical opinion was unanimous that he would not develop further. The High Court was approached in terms of section 100 of the Children Act 1989 to exercise its inherent jurisdiction and authorize medical staff not to use mechanical ventilation in any future resuscitation. In this case the court confirmed that it would not order a medical practitioner to treat a patient against his clinical judgment. ${ }^{146}$

One of the projects of the Nuffield Council on Bioethics was to draft guidelines to assist health-care professionals in critical-care decisions, and this was done by a multidisciplinary Working Party. ${ }^{147}$ The final report is entitled "Critical care decisions in fetal and neonatal medicine: ethical issues". Unlike legislation and case law that are not applicable throughout

141 Hereinafter "the RCPCH".

142 Harper Medical Treatment and the Law 48.

143 In Re OT (a Baby) supra [102-105] the court considered the Guidelines of the Royal College of Paediatrics and Child Health, "Withholding or withdrawing life sustaining treatment in children" dated May 2004. After considering the expert evidence, the court came to the conclusion that OT fell within the categories of the "no chance" and "no purpose" situations.

144 Mason and Laurie Mason and McCall Smith's Law and Medical Ethics 491.

145 In re J (a Minor) (Child in care: Medical Treatment) [1992] 3 WLR 507.

146 In re J (a Minor) (Child in care: Medical Treatment) supra 512, 514 and 519.

147 The Working Party consisted of neonatologists, an obstetrician, a professor of children's nursing research, philosophers, social scientists, lawyers, a health economist, and individuals who had worked with the families of extremely premature babes and disabled children. 
the United Kingdom, these guidelines may be consulted and applied in all three jurisdictions in the United Kingdom.

The Working Party acknowledged that making critical-care decisions during pregnancy and after the baby is born places high demands on both parents and health-care professionals. ${ }^{149}$

Various recommendations were made on different aspects of critical care, ${ }^{150}$ one of which was determining the threshold when treatment should be discontinued, in other words, when only palliative care should be provided but no treatment that would only prolong suffering. ${ }^{151}$ The Working Party considered the report of the RCPCH and decided to use the concept of "intolerability" as the criterion. ${ }^{152}$

The report considers not only clinical issues pertaining to the health care of neonates, but also legal issues: the guidelines accept the best-interests principle as the standard to be applied whenever decisions are made on children in general, and neonates in particular. ${ }^{153}$

\section{CONCLUSION}

The surrogate decision-maker and the health-care professionals responsible for treating the patient should together decide when to commence or discontinue medical treatment. Such decisions are often based on an evaluation of the potential quality of life of the baby if the treatment is successful. However, the final decision also depends to a large extent on the family into which the baby is born. Not all families may feel that they are equipped to deal with a severely handicapped baby, but some may. Here the case of David Glass, discussed above, serves as an example. His mother and aunts were prepared to look after him and give him all necessary care, no matter how disabled he was. Some authors believe that such a child, although disabled, can be considered to enjoy a good quality of life. ${ }^{154}$ It is acknowledged that critical-care decisions should be made in partnership with parents. ${ }^{155}$ This is also the view of the NCOB. ${ }^{156}$

Various points that emerged in the cases discussed in this article could make a valuable contribution to our own case law, should similar matters reach our courts. When asked to step in to resolve disputes between parents and health-care professionals, the court is faced with the difficult task of balancing the interests of the parents and the best interests of the baby, while at the same time having due regard to the clinical judgment of the health-care professionals who are responsible for the treatment of the

148 It should be noted that there are three jurisdictions in the United Kingdom, namely England and Wales, Scotland and Northern Ireland.

149 Nuffield Council in Bioethics (hereinafter "NCOB") Critical Care Decisions in Fetal and Neonatal Medicine: Ethical Issues (2006) 3.

150 Not all the recommendations will be discussed here, because of space constraints.

151 NCOB Critical Care Decisions in Fetal and Neonatal Medicine 12 and 155-156.

152 NCOB Critical Care Decisions in Fetal and Neonatal Medicine 12.

153 NCOB Critical Care Decisions in Fetal and Neonatal Medicine 15.

154 Fletcher, Holt, Brazier and Harris Ethics, Law and Nursing 147.

155 Brazier and Cave Medicine, Patients and the Law 430.

156 NCOB Critical Care Decisions in Fetal and Neonatal Medicine 23, 62 and 160. 
patient. Although section 28(2) of the Constitution provides that "a child's best interests are of paramount importance in every matter concerning the child", it was held in a number of cases that "the fact the best interests of the child are paramount does not meant that they are absolute". ${ }^{157}$ In view of this and the fact that a critically ill neonate will have a severe impact on the lives of family members, it is suggested that when the court is requested to make a decision, a holistic approach should be followed. This would entail that the interests of all the parties involved, including the parents and other siblings and not only the interests of the neonate, are taken into account.

Over the years, the courts of England and Wales have formulated a few criteria that could help our courts make decisions that would be in the child's best interests. The first criterion is whether the child's life will be "demonstrably awful". ${ }^{158}$ This was laid down in the case of Baby Alexandra, where the Supreme Court of Appeal overruled the parents' objection to surgery to remove an intestinal blockage and held that as a child born with Down's Syndrome, her life would not be "demonstrably awful".

In other cases the courts have also drawn up balance sheets of the benefits and burdens of proposed treatment. This was done for the first time in $R e J,{ }^{159}$ and again in $R e M B{ }^{160} A$ balance sheet of the benefits and burdens of treatment will help the court make the correct decision on what will be in the best interests of the child. In the re $J^{161}$ case the court also applied "intolerability" as a criterion in deciding whether to withhold or withdraw treatment. In a more recent case the test the court applied was whether the child would be able "to enjoy the simple pleasure of being alive". ${ }^{162}$

In order to decide what is in the best interests of the patient, the point of view of the patient needs to be considered. ${ }^{163}$ English and Welsh courts also reiterated that the best interests encompass medical, emotional and all other welfare issues, as well as psychological and social benefits to the child. ${ }^{164}$ In summary, it may be said that each case should be decided by the court on its own facts and merits.

Although to date in South Africa there have been no reported cases similar to the English and Welsh ones discussed above, the principles laid down in those cases can serve as precedents in South Africa. Hopefully parents of child patients in South Africa will eventually become more aware of their rights, and the courts will be afforded the opportunity to lay down relevant principles. It is also essential that these cases be heard by the

\footnotetext{
157 S v M (Centre for Child Law as Amicus Curiae) 2008 (3) SA 323 (CC) [26]. See also De Reuck v Director of Public Prosecutions, WLD 2004 (1) SA 406 [55]; Sonderup v Tondelli 2001 (1) SA 1171 (CC) [29]; and Minister of Welfare and Population Development $v$ Fitzpatrick 2000 (3) SA 433 (CC) [17]-[18].

158 In re B (a Minor) (Wardship: Medical Treatment) supra 1424.

159 In re J (a Minor) (Wardship: Medical Treatment) supra.

60 An NHS Trust v MB supra 507. See also in Re OT (a Baby) supra [99].

161 In re J (a Minor) (Wardship: Medical Treatment) supra 149.

162 Re K (Medical Treatment: declaration) supra [57].

163 NHS Trust $v$ Baby $X$ \& Ors supra.

164 In Re OT (a Baby) supra [98].
} 
courts since legal certainty is necessary in cases of disagreement between parents and health-care professionals.

In conclusion it may be mentioned that guidelines on neonatal intensive care are also needed in South Africa. These guidelines should be drafted by a disciplinary team similar to the Working Party of the Nuffield Council on Bioethics and should be applicable in both the public and private health sectors.

It should be borne in mind that guidelines are just that, merely guidelines and not legislation. However, there should be deviation from the guidelines only after careful consideration and with good reason. ${ }^{165}$ Adherence to the guidelines will also minimize litigation against hospitals and health-care professionals.

If these measures were implemented, the vulnerable group of patients that form the subject of this article would enjoy more protection under South African law.

165 Elliston in Norman and Greer (eds) Preterm Labour. Managing Risk in Clinical Practice 377. 